\title{
Pengaruh Kualitas Informasi Dalam Ulasan Online dan Kualitas Situs Web Terhadap Kepercayaan Konsumen Pada Situs Web Perjalanan Wisata (Studi Pada Traveloka)
}

\author{
Received: \\ 17 Desember \\ 2020 \\ Revision \\ received: \\ 1 Maret 2021 \\ Accepted: \\ 24 Maret 2021
}

\author{
Maya Rismayanti dan Ira Siti Sarah* \\ Jurusan Administrasi Niaga, Politeknik Negeri Bandung, Indonesia
}

\begin{abstract}
:
Travel websites are the choice of tourists to plan trips efficiently. One of the most popular travel and tour websites in Indonesia is Traveloka.com. Many obstacles and problems occur in an online business especially in terms of online consumer trust, Traveloka.com is no exception. This study aims to assess the information quality of reviews on the website, the quality of the website, customers' trust in the website, and finally the effect of information quality and website quality on online trust. This research uses a quantitative approach. The research questionnaire was distributed to 272 Traveloka.com consumers. The results found that the quality of information, website quality, and online trust of Traveloka.com consumers are at a good level. Moreover, there is a simultaneous and partial influence of the information quality in online reviews and the website quality on the customers' online trust of the Traveloka.com website by contributing a value of $29.6 \%$.
\end{abstract}

Keywords: information quality, website quality, online trust, travel website

\begin{abstract}
Abstrak:
Situs web perjalanan dan wisata menjadi pilihan para wisatawan untuk merencanakan perjalanan dengan mudah dan efisien. Salah satu agen perjalanan dan wisata yang popular digunakan yaitu situs web Traveloka.com. Seiring dengan banyaknya kendala dan masalah yang terjadi dalam jejaring bisnis online, hal ini juga dialami oleh Traveloka.com terutama dalam hal kepercayaan konsumen secara online. Penelitian ini bertujuan untuk mengetahui bagaimana kualitas ulasan dalam situs web, kualitas situs web, kepercayaan konsumen secara online terhadap web, serta pengaruh antara kualitas informasi dan kualitas situs web terhadap kepercayaan online. Penelitian ini menggunakan metode pendekatan kuantitatif. Kuesioner penelitian diuji kepada 272 konsumen Traveloka.com. Hasil dari penelitian ini menyatakan bahwa kualitas informasi, kualitas situs web dan kepercayaan secara online situs web Traveloka.com dalam ketegori baik. Kemudian ditemukan adanya pengaruh secara simultan dan parsial antara kualitas informasi dalam ulasan online dan kualitas situs web terhadap kepercayaan online situs web Traveloka.com dengan kontribusi nilai sebesar 29,6\%.
\end{abstract}

Kata kunci: kualitas informasi, kualitas situs web, kepercayaan online, situs web perjalanan wisata

\section{Pendahuluan}

Semakin populernya perjalanan dan wisata tentunya meningkatkan jumlah wisatawan. Dengan demikian, tentunya akan semakin banyak peluang bisnis di sektor agen perjalanan wisata. Sektor ini 
biasanya beroperasi dengan menjual produk atau layanan yang diperlukan wisatawan mulai dari tiket transportasi, akomodasi, tiket hiburan, reservasi restoran dan fasilitas lainnya yang dibutuhkan oleh wisatawan (Blackman, Smith, Rowe, \& Stewart, 2015). Diiringi dengan kecanggihan teknologi saat ini, tentunya sebuah bisnis harus mampu beradaptasi dalam situasi dan kondisi terkini. Untuk itu banyak agen perjalanan dan wisata yang memperluas bisnisnya dengan menyediakan produk dan layanan secara online. Situs web perjalanan wisata yang paling banyak dikunjungi untuk melakukan pembelian tiket dan reservasi hotel oleh wisatawan di Indonesia adalah Traveloka.com dengan persentase sebanyak 50,67\% (DailySocial.id, 2018). Sistem transaksi secara online tentunya menimbulkan beberapa permasalahan. Salah satu permasalahan yang umum terjadi yaitu permasalahan mengenai kepercayaan konsumen. Berdasarkan riset Digital Trust Index (Fraud Management Insights, 2017) pada sepuluh negara di kawasan Asia Pasifik, Indonesia berada di urutan ke-10 dalam tingkat kepercayaan publik terhadap transaksi secara online dengan perolehan nilai $1,8 \%$. Sebagai situs web perjalanan wisata yang paling diminati oleh wisatawan Indonesia, tidak dapat dipungkiri bahwa situs web Traveloka.com juga memiliki permasalahan yang menyebabkan berkurangnya kerpercayaan konsumen. Berdasarkan data yang dihimpun dari 100 konsumen Traveloka.com yang menulis ulasan pada situs web Traveloka.com (Google, 2020) diperoleh beberapa alasan ketidakpuasan yang mereka rasakan terhadap Traveloka.com, yaitu:

1. Informasi tidak jelas dan layanan reschedule sulit.

2. Sulit untuk melakukan pengembalian dana (refund).

3. Fasilitas tidak sesuai dengan deskripsi yang dicantumkan pada situs web.

4. Perlindungan privasi/informasi pribadi yang tidak aman.

5. Lokasi hotel tidak sesuai informasi pada situs web.

6. Kegagalan saat pembayaran.

7. Informasi harga yang berbeda pada tampilan awal dengan harga yang dibayarkan.

Permasalahan di atas sangatlah penting untuk ditinjau kembali, mengingat bahwa Traveloka.com sudah menjadi situs web yang populer digunakan oleh wisatawan. Permasalahan itu akan menjadi suatu pengalaman kurang baik bagi wisatawan untuk melakukan transaksi dan menggunakan layanan kembali di situs web Traveloka.com. Hal ini menjadikan nilai kepercayaan konsumen secara online berkurang untuk menggunakan layanan Traveloka.com.

Kendala-kendala yang dialami konsumen tersebut dapat dikaitkan dengan kualitas situs web, yaitu alat untuk mengukur sebaik apa kinerja dan kualitas keseluruhan fitur pada situs web agar situs web dapat memenuhi kebutuhan penggunanya (Mutaz, Mamoun, \& Mohamed, 2015). Apalagi dengan maraknya ulasan palsu yang ditulis oleh pihak tidak bertanggung jawab dengan mengatasnamakan konsumen. Sehingga beberapa konsumen juga merasakan ulasan pada situs web Traveloka.com tidak sesuai dengan keadaan yang sebenarnya. Hal ini tentunya sedikit merepotkan konsumen karena konsumen pada akhirnya harus melakukan riset mandiri dengan membaca ulasan yang tersedia di situs web lain. Ulasan dari pelanggan sebelumnya yang menceritakan pengalaman mereka dapat membantu konsumen lain untuk menilai kualitas produk dan layanan yang mereka rencanakan beli (Filieri, Alguezaui, \& McLeay, 2015).

Kualitas informasi ditemukan sebagai prediktor kuat untuk kredibilitas, kualitas situs web, dan kepercayaan konsumen (Filieri, Alguezaui, \& McLeay, 2015). Selain itu kualitas situs web merupakan prediktor penting bagi kepercayaan dan kepuasan pelanggan (Filieri, Alguezaui, \& McLeay, 2015). Berdasarkan latar belakang yang telah dipaparkan, penelitian ini bertujuan untuk meneliti pengaruh kualitas informasi dalam ulasan online dan kualitas situs web terhadap kepercayaan konsumen secara online pada situs web perjalanan wisata, khususnya situs web Traveloka.com.

\section{Kajian Literatur}

\section{Kualitas informasi dalam ulasan online}

Kualitas yang dinilai dalam penelitian ini merupakan informasi dalam ulasan online yang ditulis oleh konsumen dari perspektif mereka, pengalaman yang mereka miliki berupa teks dan foto-foto ke dalam situs web yang tersebar luas dan diakses oleh konsumen lainnya (Filieri, Alguezaui, \& McLeay, 2015). Kualitas informasi dalam sebuah ulasan dapat dinyatakan baik jika ulasan tersebut dapat memberikan 
informasi yang lengkap dan memenuhi kebutuhan konsumen, kemudian informasi tersebut dapat digunakan atau dimanfaatkan penggunanya dalam mengambil keputusan. Kualitas informasi yang buruk akan merusak pengalaman penggunanya dengan menghabiskan lebih banyak usaha dan waktu untuk meneliti informasi tersebut (Gao, Li, Liu, \& Fang, 2018). Penelitian ini menggunakan enam dimensi kualitas informasi (Filieri, Alguezaui, \& McLeay, 2015; Wang \& Lin, 2016) yang terdiri dari kredibel, aktual, bermanfaat, bernilai, lengkap dan relevan. Kredibel berkaitan dengan baik atau tidaknya seseorang atau sumber yang memberikan informasi (Yadianti \& Mubarok, 2017). Kriteria ini akan meyakinkan seseorang untuk menerima informasi. Informasi yang aktual artinya harus diterima tepat pada waktunya atau tepat pada saat di butuhkan (Mutaz, Mamoun, \& Mohamed, 2015). Informasi yang bermanfaat adalah informasi yang dapat dijadikan sebagai dasar atau rekomendasi dalam pengambilan keputusan (Filieri, Alguezaui, \& McLeay, 2015). Bernilai pada konteks ini adalah informasi yang berharga dan tidak dapat ditemukan di media lainnya (Agag \& El-Masry, 2016). Dimensi lengkap berarti ulasan harus bisa menampung seluruh informasi yang dibutuhkan oleh konsumen mulai dari harga, fasilitas, lokasi, dan layanan lainnya (Wang, Law, Guillet, Hung, \& Fong, 2015). Terakhir, relevan berarti bahwa seluruh informasi dalam ulasan harus relevan dengan kebutuhan masing-masing individu (Filieri, Alguezaui, \& McLeay, 2015).

Wisatawan biasanya melihat ulasan online untuk membuat keputusan dalam memilih opsi perjalanan yang akan dilakukan. Konsumen akan menggunakan internet untuk mencari seluruh informasi sebelum melakukan pembelian sebuah produk layanan (Gao, Li, Liu, \& Fang, 2018). Konsumen yang membaca ulasan ini juga kemungkinan besar adalah konsumen yang terbiasa menulis ulasan di media sosial (Sarah, Suhartanto, Setiawati, 2018).

\section{Kualitas situs web}

Kualitas situs web mengacu pada kinerja keseluruhan fitur situs web dan merupakan ukuran sejauh mana situs web dapat memenuhi kebutuhan penggunanya (Mutaz, Mamoun, \& Mohamed, 2015). Sama seperti yang disebutkan peneliti sebelumnya (Wang, Law, Guillet, Hung, \& Fong, 2015), kualitas situs web merupakan keunggulan atau keefektifan sebuah situs web dalam menyampaikan pesan kepada konsumen. Situs web yang berkualitas mendorong penggunaan situs secara berulang dalam jangka panjang (Sutisna, Prayogo, Sarah, 2019). Kualitas situs web pada penelitian ini diukur dengan menggunakan tiga dimensi (Wang, Law, Guillet, Hung, \& Fong, 2015). Pertama, dimensi fungsionalitas, yang merujuk pada kehandalan situs web dalam menyediakan layanan yang baik untuk konsumen (Giao, Vuong, \& Quan, 2020). Kedua, dimensi penggunaan, yaitu situs web harus dapat digunakan dengan mudah dan diakses dengan sederhana sehingga memudahkan konsumen (Mutaz, Mamoun, \& Mohamed, 2015) dalam memenuhi kebutuhan informasi yang diinginkan (Filieri, Alguezaui, \& McLeay, 2015). Ketiga, dimensi keamanan dan privasi, dimana situs web bisa menjamin bahwa data konsumen yang dihimpun pada situs web hanya digunakan dengan seijin konsumen. Dengan kehadiran internet, penelitian ini mengusulkan bahwa keamanan data dan privasi konsumen harus diutamakan (Filieri, Alguezaui, \& McLeay, 2015).

\section{Kepercayaan konsumen secara online}

Kepercayaan merupakan suatu karakteristik utama dari hubungan pembeli dan penjual, kepercayaan dibentuk saat konsumen mempunyai keyakinan terhadap kompetensi dan integritas pemilik usaha (Lien, Wen, Huang, \& Wu, 2015). Konsep kepercayaan konsumen secara online (online trust) dibangun seiring berkembangannya jual beli secara online (e-commerce). Penelitian terdahulu (Mutaz, Mamoun, \& Mohamed, 2015; Wang, Law, Guillet, Hung, \& Fong, 2015; Giao, Vuong, \& Quan, 2020) mengukur kepercayaan online dengan tigam dimensi yaitu kemampuan, integritas dan kebajikan. Kemampuan adalah sejauh mana situs web ini dianggap mempunyai pengetahuan dan keterampilan yang dibutuhkan untuk melakukan pekerjaan dengan benar. Integritas adalah tentang persepsi konsumen bahwa situs web perjalanan dapat memenuhi klaim yang diberikan perusahaan pemilik situs web. Kebajikan mengacu pada kepedulian tulus yang ditunujukan situs web. Hal ini didasarkan pada penilaian emosional konsumen atas niat baik perusahaan pemilik situs web (Wang, Law, Guillet, Hung, \& Fong, 2015). 


\section{Pengaruh kualitas informasi dan kualitas situs web terhadap kepercayaan online}

Beberapa penelitian sebelumnya telah membahas pengaruh kualitas informasi dalam ulasan online dan kualitas situs web terhadap kepercayaan online. Salah satunya yaitu penelitian (Filieri, Alguezaui, \& McLeay, 2015) yang menunjukkan bahwa kualitas informasi dalam ulasan online dan kualitas sebuah situs web dapat mempengaruhi kepercayaan online suatu situs web perjalanan. Kualitas informasi menjadi faktor penting dalam meningkatkan kepercayaan dan kualitas website akan mempengaruhi kepercayaan pelanggan secara online (Wang, Law, Guillet, Hung, \& Fong, 2015). Kemudian sesuai dengan penelitian selanjutnya (Wang \& Lin, 2016) bahwa kualitas informasi dapat mempengaruhi kepercayaan konsumen dalam situs web berbasis lokasi, dan situs web yang berkualitas baik dapat mempengaruhi kepercayaan secara positif dan signifikan (Giao, Vuong, \& Quan, 2020). Kerangka pemikiran dalam penelitian ini yaitu sebagai berikut:

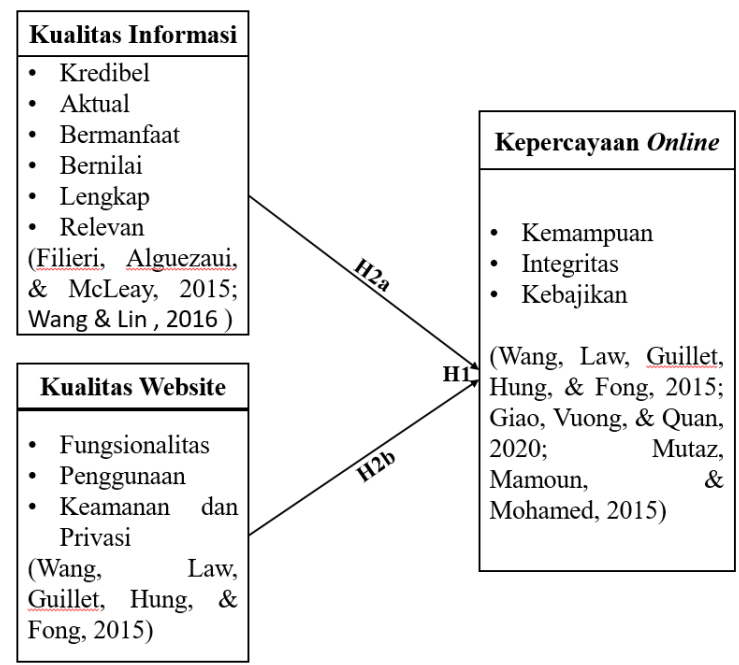

Gambar 1. Kerangka Pemikiran

Berdasarkan kerangka pemikiran tersebut, dapat diketahui hipotesis dalam penelitian ini yaitu:

H1: Adanya pengaruh secara simultan antara kualitas informasi dalam ulasan dan kualitas situs web terhadap kepercayaan online pada situs web perjalanan wisata Traveloka.com.

H2a: Adanya pengaruh secara parsial antara kualitas informasi dalam ulasan terhadap kepercayaan online pada situs web perjalanan wisata Traveloka.com.

$\mathrm{H} 2 \mathrm{~b}$ : Adanya pengaruh secara parsial antara kualitas situs web terhadap kepercayaan online pada situs web perjalanan wisata Traveloka.com.

\section{Metode Penelitian}

Penelitian ini menggunakan pendekatan kuantitatif. Untuk mengetahui mengapa suatu peristiwa berlangsung serta hal apa saja yang menjadi penyebabnya, peneliti akan memverifikasi hipotesis yang dikembangkan dengan mendistribusikan kuesioner kepada responden (Gursida \& Harmon, 2017). Analisis penelitian ini akan menggunakan perangkat lunak IBM SPSS Statistik.

Penelitian ini dilakukan pada konsumen situs web Traveloka.com di Indonesia, dengan kriteria konsumen yang sudah pernah memakai dan menggunakan layanan situs web Traveloka.com.

Teknik sampling yang dipakai purpose sampling. Karakteristik sampel ditentukan sesuai dengan yang diinginkan pada penelitian ini (Johnson \& Christensen, 2012). Untuk menjaring responden yang memenuhi syarat, sebelum pendistribusian kuesioner diajukan pertanyaan "apakah Anda pernah mengakses Traveloka.com dalam waktu 12 bulan terakhir?" dan "apakah Anda pernah membeli produk Traveloka.com seperti tiket pesawat, reservasi hotel, tiket kereta, tiket hiburan, dll dalam waktu 12 bulan terakhir?". Kuesioner menggunakan skala likert 5 poin, dengan nilai poin 1 memberikan arti sangat tidak setuju dan nilai poin 5 memberikan arti sangat setuju.

Menentukan jumlah sampel pada populasi yang tidak terhingga dapat dilakukan dengan cara jumlah item indikator dikalikan 5 hingga 10 (Hair, 2006). Dengan begitu jumlah sampel dalam penelitian yaitu 24 dikali 10, sehingga hasil yang didapatkan yaitu minimal 240 sampel. Kuesioner 
yang dikembalikan sejumlah 272, dan semuanya digunakan dalam penelitian ini.

\section{Hasil dan Pembahasan}

\section{Profil Responden}

Tabel 1 adalah data responden yang mengisi kuesioner penelitian dengan jumlah 272 responden.

Tabel 1. Data Responden

\begin{tabular}{|c|c|c|}
\hline \multicolumn{3}{|c|}{ Responden (orang) } \\
\hline $\begin{array}{l}\text { Jenis Kelamin: } \\
\text { 1. Pria } \\
\text { 2. Wanita }\end{array}$ & $\begin{array}{c}90 \\
182\end{array}$ & $\begin{array}{l}33 \\
67\end{array}$ \\
\hline Usia: & & \\
\hline 1. $17-25$ & 218 & 80 \\
\hline 2. $26-34$ & 45 & 17 \\
\hline 3. $35-43$ & 9 & 3 \\
\hline 4. $>43$ & 0 & 0 \\
\hline Pekerjaan: & & \\
\hline 1.Mahasiswa & 126 & 46 \\
\hline 2.PNS & 14 & 5 \\
\hline 3.Swasta & 90 & 33 \\
\hline 4.Wiraswasta & 26 & 10 \\
\hline 5. Lain-Lain & 16 & 6 \\
\hline Pendapatan/bulan: & & \\
\hline 1. $<\mathrm{Rp} 1$ juta & 58 & 21 \\
\hline $2.1-1,5$ juta & 44 & 16 \\
\hline 3. $1,5-2$ juta & 25 & 9 \\
\hline 4. $2-2,5$ juta & 15 & 6 \\
\hline 5. $2,5-3$ juta & 21 & 8 \\
\hline 6. $>3$ juta & 109 & 40 \\
\hline
\end{tabular}

\section{Uji Validitas dan Reliabilitas}

Uji validitas dilakukan pada 30 orang responden. Hasil dari pengujian pada variabel kualitas informasi, kualitas situs web dan kepercayaan secara online menghasilkan nilai pada korelasi item-total $>0.3610$, yang berarti nilai $\mathrm{r}$ hitung $\geq \mathrm{r}$ tabel. Dengan demikian semua item dalam instrumen penelitian dinyatakan valid.

Pengujian reliabilitas pada responden sebanyak 30 orang dilakukan dengan metode alpha cronbach. Nilai cronbach's alpha variabel kualitas informasi adalah 0,766 , kualitas situs web bernilai 0,752 sementara nilai kepercayaan online adalah 0,812. Menurut metode alpha Cronbach reliabilitas variabel-variabel ini dinyatakan baik dan dapat diterima (nilai $>0,6$ ).

\section{Analisis Deskriptif}

Dapat disimpulkan variabel kualitas informasi memiliki hasil nilai rata-rata 3,9. Nilai rata-rata tersebut dalam skala interval termasuk ke dalam kategori "baik". Sehingga dapat dinilai bahwa kualitas informasi dalam situs web Traveloka.com sudah baik. Terdapat satu indikator yang masih dalam kategori "cukup" yaitu indikator bernilai.

Tabel 2. Hasil Deskriptif Kualitas Informasi

\begin{tabular}{l|c|c|c}
\hline \multicolumn{4}{|c}{ Kualitas Informasi } \\
\hline Indikator & Min. & Maks. & Mean \\
\hline Kredibel & 1 & 5 & 4.15 \\
\hline Aktual & 2 & 5 & 4.11
\end{tabular}




\begin{tabular}{l|c|c|c} 
Bermanfaat & 1 & 5 & 4.22 \\
\hline Bernilai & 1 & 5 & 3.19 \\
\hline Lengkap & 2 & 5 & 3.68 \\
\hline Relevan & 2 & 5 & 4.09 \\
\hline \multicolumn{3}{|c|}{ Rata-rata } & $\mathbf{3 , 9}$ \\
\hline
\end{tabular}

Tabel 3. Hasil Deskriptif Kualitas Website

\begin{tabular}{l|c|c|c}
\hline \multicolumn{4}{c}{ Kualitas Situs Web } \\
\hline Indikator & Min. & Maks. & Mean \\
\hline Fungsionalitas & 1 & 5 & 4,38 \\
\hline Penggunaan & 1 & 5 & 4,17 \\
\hline $\begin{array}{l}\text { Keamanan dan } \\
\text { Privasi }\end{array}$ & 1 & 5 & 4 \\
\hline \multicolumn{4}{c}{ Rata-rata } \\
\hline
\end{tabular}

Berdasarkan hasil analisis deskriptif variabel kualitas situs web memiliki hasil nilai rata-rata 4.2. Nilai rata-rata tersebut dalam skala interval termasuk ke dalam kategori "sangat baik". Hal ini berarti situs web Traveloka.com dinilai berkualitas oleh konsumen.

Tabel 4. Hasil Deskriptif Kepercayaan Online

\begin{tabular}{l|c|c|c}
\hline \multicolumn{4}{c}{ Kepercayaan Secara Online } \\
\hline Indikator & Min. & Maks. & Mean \\
\hline Kemampuan & 2 & 5 & 3,9 \\
\hline Integritas & 1 & 5 & 3,84 \\
\hline Kebajikan & 1 & 5 & 3,65 \\
\hline \multicolumn{4}{c}{ Rata-rata } \\
\hline
\end{tabular}

Secara keseluruhan dapat disimpulkan variabel kepercayaan online yang terdiri dari dimensi kemampuan, integritas dan kebajikan memperoleh nilai rata-rata 3,8. Sehingga berdasarkan skala interval termasuk kategori "baik". Maka dapat disimpulkan bahwa konsumen mempercayai situs web Traveloka.com.

\section{Uji Asumsi Klasik}

Hasil pengujian normalitas menghasilkan nilai signifikansi $0,200(>0,05)$ sehingga menurut metode Kolmogorov-Smirnov data dalam penelitian ini memiliki distribusi yang normal.

Hasil uji linieritas untuk variabel kualitas informasi dengan kepercayaan online adalah 0,954 $(>0,05)$. Sementara hasil untuk variabel kualitas situs web terhadap variabel kepercayaan online menghasilkan angka 0,176 (>0,05). Berdasarkan metode Kolmogorov-Smirnov, hasil ini menunjukan adanya hubungan linear yang signifikan dari variabel kualitas informasi dan kualitas situs web pada kepercayaan online.

Berdasarkan hasil pengujian multikolinearitas didapatkan nilai tolerance yaitu sebesar 0,656 $(>0,10)$. Hal ini berarti tidak terdapat korelasi yang tinggi pada variabel kualitas informasi dan kualitas situs web, sehingga tidak akan mengganggu hubungan korelasi kepercayaan online sebagai variabel bebas.

Hasil uji heteroskedastisitas menunjukan variabel kualitas informasi memiliki nilai signifikan sebesar 0,407 $(>0,05)$, sementara kualitas situs web mempunyai nilai $0,141(>0,05)$. Hal ini berarti keduanya tidak mengalami heteroskedastisitas. Maka model regresi dalam penelitian bisa diterima karena tidak mengalami gejala heteroskedastisitas.

\section{Analisis Regresi Berganda}

Menurut hasil pengujian regresi diketahui rumus regresinya yaitu sebagai berikut :

$$
\mathrm{Y}=2,187+0,226+0,136
$$


Dari rumus regresi tersebut dapat diperoleh beberapa informasi yaitu:

1. Angka konstanta $\left(\beta \_0\right)$ adalah 2,187 menunjukkan bahwa variabel kualitas informasi dan kualitas situs web bernilai (x-0), maka dapat dinyatakan kepercayaan online yang dapat dicapai yaitu sebesar 2,187 .

2. Angka koefisien regresi berganda kualitas informasi (X1) adalah 0,226. Memiliki arti setiap bertambah satu angka pada kualitas informasi dengan koefisien yang bernilai positif, maka kepercayaan online meningkat pula sebesar 0,226 . Kemudian nilai koefisien regresi berganda variabel kualitas situs web yaitu 0,136 . Hal ini berarti setiap bertambah satu angka pada kualitas situs web dengan koefisien yang bernilai positif, maka kepercayaan online mengalami peningkatan sebanyak 0,136 .

3. Tingkat signifikasi dalam regresi linear berganda di atas yaitu 0,000 (atau <0,05) yang berarti bahwa regresi berganda dalam penelitian bisa digunakan untuk meramalkan kepercayaan online.

\section{Koefisien Determinasi}

Hasil penelitian menunjukan nilai R square sebesar 0,296. Sehingga bisa dinyatakan besarnya angka koefisien determinasi yaitu $29,6 \%$ yang berarti variabel bebas secara simultan memiliki pengaruh terhadap variabel terikat sebesar $29,6 \%$. Sedangkan sisanya $70,4 \%$ merupakan variabel lain yang dapat memiliki pengaruh kepada variabel kepercayaan online.

\section{Uji Hipotesis}

Dapat dilihat menurut angka nilai $\mathrm{f}$ hitung yaitu 56,521. Dan nilai $\mathrm{f}$ tabel dapat ditentukan dengan $\mathrm{f}$ tabel $=(2 ; 270)$ yaitu hasilnya 3,029. Berdasarkan keputusan uji f maka nilai f hitung 56,521 > 3,029 f tabel sehingga dinyatakan H1 diterima. Dengan demikian kualitas informasi (X1) dan kualitas situs web (X2) secara simultan dapat mempengaruhi kepercayaan online (Y) pada situs web Traveloka.com. Dari nilai f hitung sebesar 56,521 dapat diketahui bahwa terdapat arah positif dalam pengaruhnya.

Berdasarkan perolehan thitung variabel kualitas informasi (X1) adalah $4.375>$ dari nilai t tabel 1,968, maka dapat dinyatakan bahwa $\mathrm{H} 2$ a diterima. Berarti terdapat pengaruh pada variabel kualitas informasi (X1) terhadap kepercayaan online (Y). Berdasarkan perolehan thitung variable kualitas situs web (X2) yaitu $5.284>$ dari nilai t tabel 1,968, maka bisa dinyatakan bahwa $\mathrm{H} 2 \mathrm{~b}$ diterima. Hal ini berarti adanya pengaruh antara variabel kualitas situs web (X2) terhadap kepercayaan online (Y). Dari hasil nilai t hitung sebesar 4.375 dan 5.284 dapat diketahui arah pengaruh yang positif.

Tabel 5. Hasil Uji Hipotesis F Simultan

\begin{tabular}{c|c|c|c}
\hline & F hitung & F tabel & Hasil \\
\hline H1 & 56,521 & 3,029 & Diterima \\
\hline
\end{tabular}

Tabel 6. Hasil Hipotesis Uji T Parsial

\begin{tabular}{l|c|c|c}
\hline & T hitung & T tabel & Hasil \\
\hline H2a & 4.375 & 1,968 & Diterima \\
\hline H2b & 5.284 & 1,968 & Diterima \\
\hline
\end{tabular}

\section{Pembahasan}

Berdasarkan hasil analisis deskriptif, ulasan yang ditulis konsumen dalam situs web sudah berkualitas baik. Informasi pada ulasan dalam situs web sudah kredibel, informasi aktual, informasi bermanfaat bagi wisatawan, informasi cukup bernilai, informasi sudah cukup lengkap dan informasi sudah relevan sesuai dengan kebutuhan bermacam-macam wisatawan. Untuk itu ulasan dalam situs web Traveloka.com sudah mampu untuk memenuhi kebutuhan konsumen dan dapat digunakan dalam pengambilan keputusan untuk referensi perjalanan wisata yang akan dipilih konsumen (Filieri, Alguezaui, \& McLeay, 2015). Meskipun kualitas informasi dalam ulasan di situs web Traveloka.com sudah baik, namun untuk meningkatkan kualitas agar sangat baik situs web Traveloka.com harus membuat sistem atau prosedur untuk melakukan retensi ulasan yang sudah lampau agar konsumen 
tidak akan membaca ulasan yang sudah tidak sesuai dengan fasilitas terbaru saat ini. Sehingga ulasan akan lebih bernilai dan lebih aktual bagi konsumen.

Variabel kualitas situs web termasuk dalam kategori sangat baik. Traveloka.com sudah dapat dikatakan berkualitas karena memiliki nilai fungsionalitas yang baik dengan memberikan layanan dengan menyediakan informasi mengenai akomodasi, harga, lokasi, fasilitas dan promosi/diskon harga yang dibutuhkan oleh konsumen. Konsumen tidak bisa merasakan dan melihat langsung produk yang dijual di situs web, untuk itu fungsionalitas ini sangat dibutuhkan oleh konsumen. Meskipun sudah dinyatakan baik, situs web Traveloka.com perlu memberikan informasi mengenai layanan reschedule dan refund yang jelas dan konsisten. Karena sebagian besar konsumen merasakan bahwa waktu yang dijanjikan untuk proses refund tidak sesuai dengan realisasinya, yang memerlukan waktu lebih lama lebih dari 90 hari. Kemudian informasi reschedule harus konsisten karena banyak konsumen yang tidak mendapatkan fasilitas ini padahal sebelumnya dinyatakan bahwa mendapatkan fasilitas reshedule. Situs web harus bisa memberikan jaminan jika waktu tidak sesuai dengan apa yang dijanjikan.

Situs web Traveloka.com juga dinilai dapat digunakan dengan mudah oleh konsumen, dengan bahasa, informasi, tata letak yang mudah dimengerti dan dikelola dengan baik, serta desain yang mudah dipahami dan digunakan. Situs web Traveloka juga sudah baik dalam menjaga keamanan dan privasi konsumen. Traveloka dinilai baik dalam menyediakan sistem pembayaran online yang aman dan terjamin dengan garansi pihak ketiga.

Variabel kepercayaan online terhadap situs web Traveloka.com masuk dalam kategori baik. Situs web Traveloka.com dinilai dapat bertanggung jawab atas pekerjaannya dengan benar. Situs web Traveloka.com dinilai dapat dipercaya dalam melakukan transaksi dan dalam melindungi informasi keuangan konsumen agar tidak mudah diretas. Namun hal ini masih harus ditingkatkan agat lebih baik lagi, sebab terdapat oknum yang mengatasnamakan perusahaan untuk melakukan penipuan sehingga beberapa konsumen mengalami kerugian. Dari sisi integritas, situs web Traveloka.com dinilai baik dalam melindungi data pribadi konsumen dengan sertifikasi oleh pihak ketiga. Namun dengan terjadinya beberapa kasus penyalahgunaan data pribadi konsumen dalam fitur traveloka paylater, menandakan bahwa pihak Traveloka harus meningkatkan kembali pelayanannya terutama dalam hal verifikasi yang lebih ketat. Sementara berdasarkan dimensi kebajikan, konsumen mempercayai bahwa situs web Traveloka.com tidak menjual informasi data pribadi konsumen (nama, e-mail, no handphone, alamat dan lainnya).

Berdasarkan hasil uji F, kualitas informasi (X1) dan kualitas situs web (X2) secara simultan dapat mempengaruhi kepercayaan online pada situs web Traveloka.com. Hal ini berarti jika kualitas informasi dan kualitas situs web meningkat maka kepercayaan online konsumen terhadap situs web Traveloka.com akan meningkat juga. Serupa dengan hasil studi oleh (Filieri, Alguezaui, \& McLeay, 2015) bahwa kualitas informasi pada ulasan online dan kualitas situs web dapat mempengaruhi kepercayaan online pada situs perjalanan yang khusus menampilkan ulasan konsumen.

Kemudian berdasarkan hasil uji $\mathrm{T}$, kualitas informasi dapat mempengaruhi kepercayaan online secara signifikan. Hasil analisis regresi memeperoleh nilai koefisien kualitas informasi yaitu 0,226. Nilai tersebut menunjukkan arah pengaruh yang positif. Positif disini berarti konsumen sudah menilai informasi dalam ulasan di situs web Traveloka.com sangat berkualitas maka konsumen akan merasa informasi tersebut bernilai tinggi, informasi sulit ditemukan di situs web lain dan tentunya dapat digunakan sebagai kebutuhan referensi (Filieri, Alguezaui, \& McLeay, 2015). Akibatnya konsumen akan mempercayai situs web dan tidak ragu lagi untuk menggunakan Traveloka.com. Semakin baik kualitas informasi dalam ulasan online yang dirasakan konsumen di situs web Traveloka.com, maka kepercayaan konsumen terhadap situs web Traveloka.com akan semakin tinggi. Variabel kualitas situs web juga secara parsial dapat mempengaruhi kepercayaan online. Pada hasil uji regresi berganda, kualitas situs web mendapatkan nilai koefisien 0,136 . Hal ini berarti bahwa arah pengaruhnya positif. Jika kualitas situs web meningkat sebesar 0,136 maka kepercayaan online pun akan meningkat, oleh karena itu kualitas situs web dapat mempunyai pengaruh yang signifikan dan positif terhadap kepercayaan online. Situs web dapat menjadi berkualitas jika terdapat nilai fungsionalitas yang baik sehingga situs web dapat memberikan konten yang membantu konsumen untuk memenuhi kebutuhan informasi dan keinginan konsumen. Kemudian situs web dapat dinyatakan berkualitas jika dapat dengan mudah digunakan oleh konsumen tanpa membingungkan konsumen. Terakhir situs web dapat 
berkualitas jika dapat menjamin keamanan dan privasi para konsumennya. Semakin tinggi kualitas situs web maka semakin tinggi juga kepercayaan konsumen terhadap situs web tersebut.

\section{Kesimpulan}

Kualitas informasi dalam ulasan online yang ditulis konsumen pada situs web Traveloka.com dapat dinyatakan baik. Hal ini berarti bahwa ulasan dalam situs web Traveloka.com sudah kredibel, aktual, bermanfaat bagi wisatawan, informasi cukup bernilai, cukup lengkap dan informasi sudah relevan dengan kebutuhan wisatawan. Kualitas situs web Traveloka.com sudah dapat dinyatakan sangat baik, memiliki fungsionalitas yang baik, penggunaan situs web yang mudah oleh konsumen serta keamanan dan privasi yang baik. Kepercayaan online konsumen terhadap situs web Traveloka.com sudah dapat dinyatakan baik. Konsumen sudah dapat mempercayai situs web Traveloka.com. terakhir, dapat disimpulkan bahwa kualitas informasi dalam ulasan dan kualitas situs web dapat mempengaruhi secara signifikan dan positif terhadap kepercayaan online konsumen pada situs web Traveloka.com, dengan memberikan kontribusi untuk meningkatkan kepercayaan online sebesar 29,6\%.

\section{Daftar Pustaka}

Agag, G. M. \& El-Masry, A. A. 2016. "Why Do Consumers Trust Online Travel Situs webs? Drivers and Outcomes of Consumer Trust toward Online Travel Situs web," Journal of Travel Research, pp. 1-23.

Blackman, H., Smith, J., Rowe, A. \& Stewart, S. 2015. Travel \& Tourism, Oxford: Heinemann Educational Publishers.

DailySocial.Id, "Laporan DailySocial: Survey Online Travel Agencies (OTA) 2018," 22 Februari 2018. [Online]. Available:https://dailysocial.id/post/laporan-dailysocial-survey-online-travel-agenciesota-2018.

Filieri, R., Alguezaui, S. \& McLeay, F. 2015. "Why do travelers trust Tripadvisor? Antecedents of trust towards consumer-generated media and its influence on recommendation adoption and word of mouth," Tourism Management, pp. 51, 174-185.

Fraud Management Insights. 2017. "Fraud Management Insights 2017 Digital Trust Index" [Online]. Available: $w w w . e x p e r i a n . c o . i d>w p-c o n t e n t>$ uploads.

Gao, L., Waechter, K. A. \& Bai, X. 2015. "Understanding consumers' continuance intention towards mobile purchase: A theoretical framework and empirical study - A case of China," Computers In Human Behavior, pp. Vol. 53, 249-262.

Giao, H. N., Vuong, B. N. \& Quan, T. N. 2020. "The influence of situs web quality on consumer's eloyalty through the mediating role of e-trust and e-satisfaction: An evidence from online shopping in Vietnam," Uncertain Supply Chain Management, pp. 351-370.

Google, "Google Review," 11 Juli 2020. [Online]. Available: https://play.google.com/store/apps/details?id=com.Traveloka.com.android\&hl=en\&showAllRevi ews=true.

Gursida, H. \& Harmon. 2017. Metode Penelitian Bisnis dan Keuangan Konsep dan Implementasinya, Bogor: PASPI.

Hair. 2006. Multivariate Data Analysis Edisi 5, Jakarta: Gramedia Pustaka Utama.

Johnson B. \& Christensen, L. 2012. Educational Research: Quantitative, Qualitative, and Mixed Approaches, California: SAGE Publications.

Lien, C.-H., Wen, M.-J., Huang L.-C.\& Wu, K.-L. 2015. "Online hotel booking: The effects of brand image, price, trust and value on purchase intentions," Asia Pacific Management Review, pp. 1-9.

Mubarok, L. \& Yadianti, M. A. 2017. Kualitas Pelaporan Keuangan: Kajian Teoritis dan Empiris Edisi Pertama, Jakarta: Kencana.

Mutaz, M. A., Mamoun, N. \& Mohamed, I. A. 2015. "Consumer attitudes towards online shopping: The effects of trust, perceived benefits, and perceived web quality," Internet Research, vol. 25, no. 5, pp. pp.707-733.

Sarah, I. S., Suhartanto, D. \& Setiawati, L. 2018. "Examining Electronic Word-Of-Mouth Communication in Social Media Context," International Conference on Information Technology Systems and Innovation (ICITSI), pp. 295-299. 
Sutisna, M., Prayogo, A. D. \& Sarah, I. S. 2019. "Evaluating Website Repeat Usage Using Webqual 4.0: a Guide for E-Commerce Business," IOP Publishing, IOP Conference Series: Materials Science and Engineering Vol. 662, No. 2, p. 022105.

Wang, E. S. T. \& Lin, R. L. 2016. "Perceived quality factors of location-based apps on trust, perceived privacy risk, and continuous usage intention," Behaviour \& Information Technology.

Wang, L., Law, R., Guillet, B. D., Hung, K. \& Fong, D. K. C. 2015."Impact of hotel situs web quality on online booking intentions: eTrust," International Journal of Hospitality Management, pp. (47), 108-115.

*Email korespondensi:

ira.sarah@polban.ac.id 